\title{
Prospects for the Turkish Gastronomy Tourism
}

\author{
By Mehmet Sarıŏlan*
}

\begin{abstract}
Gastronomy has not only been gaining more and more attention lately but it also has evolved to being an integral part of the every-day life in modern societies. The reason for this lies in the fact that it fulfills not only physical but also cultural, social and psychological needs. In this context, exquisite performance in the field of gastronomy attracts worldwide interest and admiration, with gastronomy tourism naturally emerging as a new and quite popular concept; the one of the pursuit of unique and memorable eating and drinking experiences. The aim of this study being the analysis of the specific characteristics and determinants of the modern, tourism industry developing around gastronomy, it is based on the examination of existing market structures as well as future developments. For this purpose, the research method selected is the analysis of a case study on both the empirical and the theoretical level. The example of Turkey, where gastronomy tourism with its special characteristics has been flourishing lately serves as a suitable base for suggesting a strategic plan for improving the industry by exploiting the dynamics of its huge potential.
\end{abstract}

\section{Introduction}

Tourism industry, demonstrating notably rapid growth, has a significant share of the global gross product today. In this context, the proportion of expendable individual and household income allocated to tourism products and services has also been rising, as the rapid improvements in communication technology stimulate people's tendency towards visiting places they have never seen before and gaining new cultural experiences (Dasgupta 2011, Franklin 2003). According to the estimations of the Global Tourism Organization, the value of the tourism product will reach 1.6 billion while tourism income will exceed the threshold of two trillion by 2020. The overall socioeconomic contribution of the industry to national economies is considered to be valuable as it boosts employment, national income and balance of payments at the same time when it causes the external-internal debt to decrease, serving the ultimate goal of overall welfare increase (Bulut 2000, Çoban and Özcan 2013). Consequently, the majority of the countries, the developing ones in particular, struggle for getting the largest possible "slice" of this cake according to their supply potential (Hepaktan and Çınar 2010, Bahar 2006).

Another reason for which tourism is regarded as a socially beneficial sector of economic activity is that it helps in preserving world peace not only thanks to its positive impact on foreign exchange flow and employment but also because it provides the basis for cultural and social communication on the international level. When the specific case of Turkey is considered, being one of the cornerstones of its economy, tourism industry attracts the state's

*Assistant Professor, Balıkesir University, Turkey. 
attention in its attempt to come up with an effective remedy for foreign trade deficit, inflation and unemployment (Woodside and Martin 2007, Çımat and Bahar 2003).

\section{The Current State of Turkish Tourism Industry}

It has been reasonably argued that the Turkish tourism industry efficiently carries out the task of the locomotive of national improvement with the huge progress it has made, especially after 1980. In the context of the decisions taken in 24 January 1980, import substitution policy was abandoned and export-oriented industrialization, considered to be the main prerequisite for establishing a free-market economy in Turkey, was introduced (Bahar 2006). A new attitude towards tourism was adopted according to which it is regarded as an easy, efficient, productive and relatively cheap tool for realizing the plan of export-oriented industrialization and should be utilized as such. Taking a look at the relevant figures further supports the above argument: the share of tourism in Turkish gross national product (GNP) increased from 0.6\% (1980) to $4.7 \%$ (2013), its share in export revenue increased from $11.2 \%$ to $24.3 \%$ while the relevant share in narrowing foreign trade deficit increased from $6.5 \%$ to $26.2 \%$ during the same period (Turkish Statistical Institute 2013). Besides, the growth of tourism industry lead to massive job creation for the Turkish standards, resulting in increased employment (of over one million employed people) which corresponds to $5.5 \%$ of the working population in Turkey today. If informal employment is reckoned, the number of the employed individuals goes up to 2.5 million (Turkish Ministry of Development 2013).

Despite the astounding performance the tourism industry has demonstrated within the boundaries imposed by the specificity of the Turkish economy (Hara 2008), Turkish tourism industry data show that there is a quite large gap between qualitative and quantitative tourism growth (Yildiz 2011). Evidently, the level of qualitative tourism growth falls behind the quantitative growth. Quantitative growth (measured in incoming tourists) is estimated to the level of $300 \%$ during the period between 2001 and 2012 while negative qualitative growth (measured in average expense per tourist) of a level of around $15 \%$ is observed in the same period (Turkish Ministry of Culture and Tourism 2013, Turkish Statistical Institute 2013). In the light shed by these data, it will be argued in this paper that there is space for both increasing the quantitative growth of Turkish tourism industry and achieving the target of positive qualitative growth.

According to the figures available by the national statistical service, Turkish tourism industry has been constantly rising through time. The number of tourists coming to Turkey was equal to 10.4 million in 2000, 21.5 million in 2005 and it is estimated to reach nearly 35 million in 2013. As discussed above, Turkish tourism industry gained speed quantitatively, yet it could not achieve qualitative growth with the rate of expense per tourist coming to Turkey decreasing every year. The global average of the expense rate per tourist is nearly 1,035 USD, while this rate is approximately 680 USD in 
Turkey. In order for qualitative as well as quantitative growth to increase further, Turkish tourism industry should head towards and try to adapt to the international standards associated to high expense rates per capita. In this context, gastronomy tourism comes in the centre of attention as the most efficient tourism type for Turkish tourism industry to grow qualitatively (Sarıoğlan 2013).

The cultural diversity and uniqueness of Turkish cuisine is considered to have significant potential for improving gastronomy tourism as well as the general tourism product qualitatively. Defined as the cradle of civilization and having hosted many different, distinct cultures, Anatolia is regarded as the most important element that shapes Turkish cuisine's culture and diversity. Within this scope, these characteristics of the Turkish cuisine elevate it to one of the three great cuisines worldwide, along with the French and the Chinese cuisines. However, Turkish tourism industry is unable to utilize its current potential in gastronomy tourism. The most important reason is that there is no promotion strategy such as the provision of a geographical map of the various gastronomic elements of the Turkish cuisine for the tourists In this context, the basic point made by this study is that there is a need for a promotion strategy of gastronomy elements in Turkey (Avcikurt et al. 2007, Aymankuy and Sarığlan 2007).

\section{The Current State of Gastronomy Tourism}

According to World Tourism Organization, there are 300 different types of tourism to invest in. However, it is not profitable to make all these investments in the context of one country and it is the responsibility of the public and private investors to choose the appropriate ones according to each country's specific characteristics and act accordingly. Turkey is lucky enough to be able to host various tourism types thanks to its natural, cultural and historical background. However, the state as well as the private initiative in its majority appears to fail to recognize the importance of diversifying the tourism product and performing different marketing and sales activities for each type. Being a company that does research on the diversity of the tourism product globally, Specialty Travel says that Turkey can engage in the provision of at least eighty five different tourism products with ease. If the tourism products and services are diversified on the basis of a well-designed plan, alternative tourism types could be introduced in the country and the Turkish tourism product could appeal to broader audiences (Güzel 2010, Turkish Ministry of Cultrure and Tourism 2007). There are many different products which could be provided by the Turkish industry and ensure the needed qualitative growth. However, the most advantageous one is the gastronomy product as the Anatolian region is ideal for its development (Göker 2012, Görkem and Öztürk 2011).

Gastronomy tourism is currently among the developing tourism types in the world. According to many relevant studies, the regions that emphasize in offering local products could increase their popularity more by raising awareness regarding their specificity (Karahan et al. 2013). Being a cultural 
element in its nature, gastronomic diversity has been a tourist attraction and it has also enabled the preservation and development of cooking and eating habits in the region. The activity of eating can be ordinary in some cultures while it can be more spiritual and multi-dimensional, in the sense that it incorporates various meanings, in some others. This variety creates to visitors the sense of breaking some taboos regarding food and it also arouses their desire to be liberated by these new taste experiences. As a result, people tend to travel to regions where there are different tastes in order to satisfy this curiosity of theirs (Hjalager and Richards 2004). Nowadays that the desire for new tastes is increasing new tourism-related opportunities wait to be grasped. In order for the Turkish tourism industry to keep up to this developments, the production process of the variety of the Turkish meals and disserts should be analyzed thoroughly from the selection of the raw materials to the consumption stage and suitable market techniques should be employed. For instance, the Turkish gastronomy marketing could be based on those raw materials and their special characteristics attributed to their local production. Highlighting the advanced quality of raw materials being produced in each region and linking it to the very fact that their production is local should attract tourists' interest in the regions where "food tastes uniquely". If the marketing ideas proposed above were to be realized appropriately, they could shape visitors' preferences regarding their holiday destinations and create loyal admirers of the Turkish countries and villages (Yüncü 2010, Kivela and Crotts 2006).

Gastronomy tourism could contribute in increasing Turkey's market share and tourism incomes by attracting high-income tourists, positively influencing the expense per tourist, decreasing seasonality and spreading tourism demand into the 12 months of the full year (Durlu-Özkaya et al. 2013). Ottoman and Turkish cuisine, which are considered to be among the richest cuisines in the world, could be the basis of a broad touristic market with the right destination branding, positioning and image (Hatipoğlu et al. 2013, Henderson 2009).

Recently, the interest in good food in Europe has become literally a movement with gourmet and gastronomy tours emerging as the most popular tourism products for intellectual, high-income tourists. Groups that organize tours to Italy or France for exploring an ethnic cuisine and for a good local drink experience are only a few among many examples indicating the development of gastronomy tourism (Conway and Timms 2010). Barcelona gained an important part of its tourism income from gastronomy, thanks to its food-beverage activities held every year. Tourists going to Loire, France to taste cheese; going to Smola, Norway for salmon; to Sontos, Brazil for coffee and to the Catalan region in Spain for Gaspacco soup could be seen as examples of gastronomy tourism (Kivela and Crotts 2005).

The fact that the share of gastronomy tourism demonstrates an upward trend is also supported by the hard figures. According to Table 1, international tourism was on average growing by $6 \%$ yearly in the 1990-2015 period, while gastronomy tourism showed annual growth of about $15.5 \%$ on average during the same period. Apparently, it showed nearly 2.5 times greater quantitative 
growth compared to overall international tourism in terms of annual average growth rates in 1990-2015.

Table 1. The Place of Gastronomy Tourism in International Tourism Movements

\begin{tabular}{|l|c|c|c|c|}
\hline \multirow{4}{*}{ Years } & \multicolumn{2}{|c|}{$\begin{array}{c}\text { International } \\
\text { Tourism Movements }\end{array}$} & \multicolumn{2}{c|}{$\begin{array}{c}\text { International Gastronomy } \\
\text { Tourism Movements }\end{array}$} \\
\cline { 2 - 5 } & $\begin{array}{c}\text { Volume of } \\
\text { Average } \\
\text { Touristic } \\
\text { Movement } \\
\text { (million people) }\end{array}$ & $\begin{array}{c}\text { Yearly } \\
\text { Average } \\
\text { Change Rate } \\
\text { (\%) }\end{array}$ & $\begin{array}{c}\text { Volume of } \\
\text { Average } \\
\text { Touristic } \\
\text { Movement } \\
\text { (million people) }\end{array}$ & $\begin{array}{c}\text { Yearly } \\
\text { Average } \\
\text { Change Rate } \\
\text { (\%) }\end{array}$ \\
\hline $\mathbf{1 9 9 0 - 1 9 9 5}$ & 472 & 3.42 & 3,74 & 4.98 \\
\hline $\mathbf{1 9 9 6 - 2 0 0 0}$ & 598 & 4.95 & 4,98 & 6.63 \\
\hline $\mathbf{2 0 0 1 - 2 0 0 5}$ & 714 & 3.87 & 9,54 & 15.26 \\
\hline $\mathbf{2 0 0 6 - 2 0 1 0}$ & 923 & 8.23 & 20,62 & 23.53 \\
\hline $\mathbf{2 0 1 1 - 2 0 1 5}$ & 1,368 & 9.64 & 48,79 & 27.32 \\
\hline
\end{tabular}

Source: World Tourism Organization 2013, Turkish Ministry of Culture and Tourism 2013, Turkish Statistical Institute 2013.

As individuals who choose gastronomy tourism generally belong to the high ends of their country's income distribution, their expenditure rates per capita are quite high. As shown in Table 2, there was a nearly $6.2 \%$ annual growth in the incomes obtained from international tourism movement during 1990-2015, while gastronomy tourism showed approximately $12.9 \%$ annual growth in the same period. Gastronomy tourism demonstrated approximately double qualitative growth compared to international tourism in this specific period.

Table 2. The Place of Gastronomy Tourism Incomes in International Tourism Incomes

\begin{tabular}{|l|c|c|c|c|}
\hline \multirow{4}{*}{ Years } & \multicolumn{2}{|c|}{$\begin{array}{c}\text { International } \\
\text { Tourism Movements }\end{array}$} & \multicolumn{2}{c|}{$\begin{array}{c}\text { International Gastronomy } \\
\text { Tourism Movents }\end{array}$} \\
\cline { 2 - 5 } & $\begin{array}{c}\text { Average } \\
\text { Touristic } \\
\text { Expenditure } \\
\text { per capita \$) }\end{array}$ & $\begin{array}{c}\text { Yearly } \\
\text { Average } \\
\text { Change Rate } \\
(\%)\end{array}$ & $\begin{array}{c}\text { Average } \\
\text { Touristic } \\
\text { Expenditure } \\
\text { per capita \$) }\end{array}$ & $\begin{array}{c}\text { Yearly } \\
\text { Average } \\
\text { Change Rate } \\
(\%)\end{array}$ \\
\hline $\mathbf{1 9 9 0 - 1 9 9 5}$ & 348 & 5.12 & 234 & 7.67 \\
\hline $\mathbf{1 9 9 6 - 2 0 0 0}$ & 461 & 6.49 & 357 & 10.51 \\
\hline $\mathbf{2 0 0 1 - 2 0 0 5}$ & 617 & 6.76 & 589 & 13.59 \\
\hline $\mathbf{2 0 0 6 - 2 0 1 0}$ & 835 & 7.06 & 1,012 & 14.36 \\
\hline $\mathbf{2 0 1 1 - 2 0 1 5}$ & 1,083 & 5.94 & 1,786 & 15.29 \\
\hline
\end{tabular}

Source: World Tourism Organization 2013, Turkish Ministry of Culture and Tourism 2013, Turkish Statistical Institute 2013. 


\section{Gastronomy Tourism in Turkey}

The Turkish cuisine is the third greatest cuisine of the world, after the Chinese and the French cuisine (Güler 2010) providing the country with a great comparative advantage for investing in this type of tourism. This comparative advantage could also serve as the decisive factor in favour of Turkey in the competition against the other Mediterranean countries which are among the biggest rivals of the Turkish tourism industry. Gastronomy tourism also increases considerably invisible export rates thanks to the fact that it stems from national culture itself and that it provides a food and beverage collection from local resources (Sarığlan 2013). Research on this topic has shown that the invisible export rate associated to gastronomy tourism is nearly $36.87 \%$ higher compared to other tourism types (Turkish Statistical Institute 2013). Touristic movements can also be seen in the full year decisively dealing with the problem of seasonality, as gastronomy tourism is independent from weather conditions. Additionally, seasonal unemployment problems could be solved by this elimination of seasonality (Long 2004).

National tourism movements were annually growing by $9.4 \%$ on average during 1990-2015, while gastronomy tourism showed annual growth of $15.5 \%$ during the same period. Gastronomy tourism showed about 1.7 times faster quantitative growth than national tourism during 1990-2015 (Table 3).

Table 3. The Place of National (Turkey) Tourism Movements in International Tourism Movements

\begin{tabular}{|l|c|c|c|c|}
\hline \multirow{4}{*}{ Years } & \multicolumn{2}{|c|}{$\begin{array}{c}\text { National (Turkey) } \\
\text { Tourism Movements }\end{array}$} & \multicolumn{2}{c|}{$\begin{array}{c}\text { International Gastronomy } \\
\text { Tourism Movements }\end{array}$} \\
\cline { 2 - 5 } & $\begin{array}{c}\text { Average } \\
\text { Touristic } \\
\text { Movement } \\
\text { (million people) }\end{array}$ & $\begin{array}{c}\text { Yearly } \\
\text { Average } \\
\text { Change Rate } \\
(\%)\end{array}$ & $\begin{array}{c}\text { Average } \\
\text { Touristic } \\
\text { Movement } \\
\text { (million people) }\end{array}$ & $\begin{array}{c}\text { Yearly } \\
\text { Average } \\
\text { Change Rate } \\
\text { (\%) }\end{array}$ \\
\hline $\mathbf{1 9 9 0 - 1 9 9 5}$ & 6,72 & 7.61 & 3,74 & 4.98 \\
\hline $\mathbf{1 9 9 6 - 2 0 0 0}$ & 8,81 & 6.24 & 4,98 & 6.63 \\
\hline $\mathbf{2 0 0 1 - 2 0 0 5}$ & 12,96 & 9.47 & 9,54 & 15.26 \\
\hline $\mathbf{2 0 0 6 - 2 0 1 0}$ & 22,57 & 14.83 & 20,62 & 23.53 \\
\hline $\mathbf{2 0 1 1 - 2 0 1 5}$ & 32,64 & 8.92 & 48,79 & 27.32 \\
\hline
\end{tabular}

Source: World Tourism Organization 2013, Turkish Ministry of Culture and Tourism 2013, Turkish Statistical Institute 2013.

The income obtained from national tourism movements grew by approximately $2.8 \%$ on average every year of the $1990-2015$ period, while gastronomy tourism showed approximately $12.9 \%$ annual growth in the same period. Gastronomy tourism showed nearly 4.5 times greater qualitative growth in terms of yearly growth rates in 1990-2015 (Table 4). 
Table 4. The Place of National (Turkey) Tourism Incomes in International Tourism Incomes

\begin{tabular}{|l|c|c|c|c|}
\hline \multirow{4}{*}{ Years } & \multicolumn{2}{|c|}{$\begin{array}{c}\text { National (Turkey) } \\
\text { Tourism Movements }\end{array}$} & \multicolumn{2}{c|}{$\begin{array}{c}\text { International Gastronomy } \\
\text { Tourism Movements }\end{array}$} \\
\cline { 2 - 5 } & $\begin{array}{c}\text { Average } \\
\text { Touristic } \\
\text { Expenditure } \\
\text { (per capita \$) }\end{array}$ & $\begin{array}{c}\text { Yearly Average } \\
\text { Change Rate } \\
(\%)\end{array}$ & $\begin{array}{c}\text { Average } \\
\text { Touristic } \\
\text { Expenditure } \\
\text { per capita \$) }\end{array}$ & $\begin{array}{c}\text { Yearly Average } \\
\text { Change Rate } \\
(\%)\end{array}$ \\
\hline $\mathbf{1 9 9 0 - 1 9 9 5}$ & 603 & 8.46 & 234 & 7.67 \\
\hline $\mathbf{1 9 9 6 - 2 0 0 0}$ & 801 & 24.71 & 357 & 10.51 \\
\hline $\mathbf{2 0 0 1 - 2 0 0 5}$ & 775 & -3.24 & 589 & 13.59 \\
\hline $\mathbf{2 0 0 6 - 2 0 1 0}$ & 716 & -7.61 & 1,012 & 14.36 \\
\hline $\mathbf{2 0 1 1 - 2 0 1 5}$ & 658 & -8.11 & 1,786 & 15.29 \\
\hline
\end{tabular}

Source: World Tourism Organization 2013, Turkish Ministry of Culture and Tourism 2013, Turkish Statistical Institute 2013.

\section{Result and Recommendations}

In the light shed by the figures above, the quantitative and qualitative growth necessary for the improvement of the Turkish tourism industry could only be achieved by the focusing on the development of gastronomy tourism. The most important element in the evolution of gastronomy tourism sector is designing a gastronomy promotion strategy regarding what specific food\& drink experiences are available to the visitors to enjoy and where they can enjoy them. In this context, a gastronomy map, should be produced and offered to visitors. There are six different gastronomy maps in France, five in Spain and Italy, four in Mexico and China, which cannot be a coincidence as all of them are countries with important market shares in gastronomy tourism. In summary, it is argued that gastronomy maps, as a marketing technique, and the touristic market share obtained from gastronomy tourism are directly proportional. Turkish tourism industry definitely needs to carefully design such a map in order to develop gastronomy tourism and acquire the desired market share.

\section{References}

Avcıkurt C, Sarığlan M, Girgin GK (2007) A Sociologial View of Food and Beverage. I. National Gastronomy Congress, 4-7 May 2007, Antalya, Turkey.

Aymankuy Y and Sarığlan M (2007). A Model Suggestion to Develop Food and Beverage Philosophy and Nourishment Habits. I. National Gastronomy Congress, 4-7 May 2007, Antalya, Turkey.

Bahar O (2006) Turizm sektörünün Türkiye'nin ekonomik büyümesi üzerindeki etkisi: VAR analizi yaklaşımı [The effect of tourism sector on the economic growth of Turkey: VAR analysis approach]. Celal Bayar Üniversitesi Yönetim ve Ekonomi Dergisi 13(2): 137-150. 
Bulut E (2000) Türk turizminin dünya'daki yeri ve dış Ödemeler bilançosuna etkisi [Turkish tourism situation of the world and effect of external balance of payments]. Gazi Üniversitesi İktisadi ve İdari Bilimler Fakültesi Dergisi (3): 7186.

Çımat A and Bahar O (2003) Turizm sektörünün Türkiye ekonomisi içindeki yeri ve önemi üzerine bir değerlendirme [An assessment of tourism sector and its significance in the turkish economy] Akdeniz I.I.I.B.F. Dergisi (6): 1-18.

Çoban O and Özcan CC (2013) Türkiye'de turizm gelirleri-ekonomik büyüme ilişkisi: nedensellik analizi (1963-2010) [The relationship between economic growth and tourism income of Turkey: a casuality analysis (1963-2010)] Eskişehir Osmangazi Üniversitesi İ.I.B.F. Dergisi 8(1): 243-262.

Conway D and Timms BF (2010) Re-branding alternative tourism in the Caribbean: the case for slow tourism. Tourism and Hospitality Research 10(4): 329-344.

Dasgupta D (2011) Tourism Marketing. New Dehli, India: Dorling Kindersley.

Durlu-Özkaya F, Sünnetçioğlu S, Can A (2013) Sürdürülebilir gastronomi turizmi hareketliliğinde coğrafi işaretlemenin rolü [The role of geographical indication in sustainable gastronomy tourism mobility]. Turizm ve Gastronomi Çalışmaları Dergisi 1(1): 13-20.

Franklin A (2003) Tourism: An Introduction. California, USA: SAGE Publication.

Göker G (2012) Destinasyon Çekicilik Unsuru Olarak Gastronomi Turizmi (Ballkesir İli Örneği) [Gastronomy Tourism as an Element of Destination Attraction (An Example of Balıkesir)]. Balıkesir Üniversitesi Sosyal Bilimler Enstitüsü [Balıkesir University Social Sciences Institute Master Thesis].

Görkem O and Öztürk Y (2011) Otel mutfaklarında stajyer istihdamı ve beceri eğitimi yeterliliğine yönelik bir uygulama [Trainee emploment in hotel kitchens and an application for qualification of skill education]. Işsletme Araştırmaları Dergisi 3(4): 18-33.

Güler S (2010) Türk mutfak kültürü ve yeme içme alışkanlıkları [Turkish kitchen culture and food-beverage habit], Dumlupınar Üniversitesi Sosyal Bilimler Enstitüsü Dergisi 26(2): 24-30.

Güzel Ö (2010) Turistik ürün çeşitlendirmesi kapsamında yeni bir dinamik: inanç turizmi [A new dynamic within touristic product diversity: faith tourism]. Süleyman Demirel Üniversitesi Vizyoner Dergisi 2(2): 87-100.

Hara $\mathrm{T}$ (2008) Quantitative Tourism Industry Analysis. Burlington, USA: Butterworth-Heinemann.

Hatipoğlu A, Zengin B, Batman O, Şengül S (2013) Yöresel yemeklerin, kırsal turizm işletmeleri menülerinde kullanım düzeyleri: Gelveri örneği [Usage levels of local foods on the menus of rural tourism establishments: sample of Gelveri]. Uluslararast Sosyal ve Ekonomik Bilimler Dergisi 3(1): 6-11.

Hepaktan CE and Çınar S (2010) Turizm endüstrisinin Türkiye ekonomisi üzerindeki etkileri [The effect of tourism industry in Turkey economics]. Celal Bayar Üniversitesi, Yönetim ve Ekonomi Dergisi 13(2): 137-150.

Henderson JC (2009) Food Tourism Reviewed. London: Emerald Group Publishing Limited.

Hjalager AM and Richards G (2004) Tourism and Gastronomy. London: Routledge.

Karahan M, Bal V, Çağatay U (2013) Turizm potansiyelinin değerlendirilmesi ve gelişiminde yerel aktörlerin rolü: Gaziantep örneği [Evaluation and development of tourism potential - the role of local actors: the case of Gaziantep]. Finans, Politik and Ekonomik Yorumlar 50: 578. 
Kivela J and Crotts JC (2006) Tourism and gastronomy: gastronomy's influence on how tourists experience a destination. Journal of Hospitality and Tourism Research 30(3): 354-377.

Kivela J and Crotts JC (2005) Gastronomy tourism. Journal of Culinary Science and Technology 4(3-4): 39-55.

Long LM (2004) Culinary Tourism. Lexington: The University Press of Kentucky.

Sarığlan M (2013) Industrial provision of practice skills of students training gastronomy education: case of Turkey. International Journal on New Trends in Education and their Implication 4(4): 216-220.

Turkish Statistical Institute (2013) Foreign Trade Data. Retrieved from: http://www. tuik.gov.tr/.

Turkish Ministry of Development (2013) Employment Data. Retrieved from: http:// www.mod.gov.tr/.

Turkish Ministry of Culture and Tourism (2007) Turkey Tourism Strategy-2023. Retrieved from: http://www.kultur.gov.tr/

Turkish Ministry of Culture and Tourism (2013) Tourism Data. Retrieved from: http:// www.kultur.gov.tr/

Yildiz Z (2011) Turizm sektörünün gelişimi ve istihdam üzerindeki etkisi [Development of tourism sector and its effects on employment]. Süleyman Demirel Üniversitesi Vizyoner Dergisi 3(5): 54-71.

Yüncü HR (2010) Sürdürülebilir turizm açısından gastronomi turizmi ve perşembe yaylas1 [Gastronomy tourism aspect of sustainable tourism and perşembe plateau]. Aybastı-Kabataş Kurultayı Aybastı-Kabataş Kurultayı Yayınları No: 11. Detay Anatolia Akademik Yayıncllık Ltd. Şti.

Woodside A and Martin A (2007) Tourism Management. Cambridge: Biddles.

World Tourism Organization (2013). Highlights. Retrieved from: http://www2.unw to.org/. 
